\title{
Increasing Youth Employability in Albania by Enhancing Skills through Vocational Education
}

\author{
Enkeleda Fejzulla Pano \\ Ph.D. candidate, University of Tirana, Faculty of Social Sciences, \\ Department of Pedagogy and Psychology, Albania
}

\begin{abstract}
Since the 1990s, Albania has experienced structural changes in education and the labour market as a result of increased globalization, the trend toward deindustrialization, and the increasing outflow of foreign direct investment, particularly from European countries such as Italy, Greece, and Turkey. Youth unemployment has increased drastically due to the transition of the economy from agricultural and public sector sectors into open market economy. This article through in-depth literature review aim to analyse the various variables and causes of youth unemployment, to analyse also the vocational education and training framework in Albania. Three research questions were raised: What are the factors that have contributed to the youth unemployment in Albania? What technical skills required the labour market in Albania? Can vocation education system in Albania enhance skills required by the labour market? This article suggests some discussions on how to increase youth employment by knowing what skills the labour market request especially in private sector and how we can improve them through vocational education and training.
\end{abstract}

Keywords: youth employment, vocational education framework, labour market, skills

\section{Introduction}

Albania in the last two decades has moved from being Europe's poorest country to an upper-middle-income country. However, the production base is limited, and the competitiveness of the primarily small businesses remains low, limiting the capacity for job creation and increased productivity. As in modern societies, also in Albania knowledge and education are central to human activities and production processes. Changes in the labour market are emphasizing the importance of individuals who can adapt to innovation, high technical skills, and the constant demand for change. As a result, greater emphasis is being placed on the importance of human capital and their technical skills to economic growth. According to INSTAT (2016) today's young 
people (aged 15-29), who generally have more education than previous generations, find it especially difficult to enter labour markets: at 28 percent, their unemployment rate is twice as high as that of the working-age population (aged 15-64). Youth unemployment is being addressed by the Government through many reforms in vocational education and employment reforms. One of them is the adoption of the National Employment and Skills Strategy (NESS) 2014-2020 in 2014 who was regarded as a milestone because it was the first time that a national strategy paper addressed employment promotion and vocational skills development as a singular entity in Albania.

Since Albania's current youth transition patterns appear complicated, blended, and lengthy. Vocational Education and Training (VET) can improve tomorrow's workforce, and thus plays an important role in economic growth, job creation, and social stability. (UNDP Albania, 2020, p.8). According to Harteis (2017), the primary goal of vocational and professional education and training is to develop an individual's skills and abilities so that the individual is well prepared for the demands of the workplace. The aim of the study is to analyse, to deepen the understanding of the main barriers and potential opportunities in increasing Albanian youth employment. And also, to analyse the role of Vocational Education in enhancing the skills required by the job market.

\section{Research Methods}

The methodology used is descriptive research design through an in-depth literature review of journals, articles, previous studies, official reports, documentations, etc in the field of youth unemployment, skills, labour market requirements, and vocational education. Also for the methodology of this study, a qualitative method was used in which 20 semi-structured interviews were used. The sample is composed of 10 business owners in the hospitality, tourism, and human resources sectors and 10 vocational education experts such as policymakers, vocational education school principals, and researchers in Tirana.

The hypothesis of the study is: "A good vocational education and training system by enhancing technical skills can increase youth employment in Albania". Three research questions were raised as follow:

- What are the factors that have contributed to youth unemployment in Albania?

- What technical skills required in the labour market in Albania?

- Can the vocation education system in Albania enhance skills required by the labour market? 


\subsection{Findings}

\subsubsection{Theoretical and empirical literature review}

\subsubsection{Variables and causes of youth unemployment}

The creation of new job opportunities is a complex challenge that involves stimulating macroeconomic policies, a favorable business climate, and forceful and coherent educational policies.

Serjanaj, L., \& Guga, K. (2017) summarize the determinants of youth unemployment that differ according to individual characteristics such as age, gender, marital status, education, and training. Furthermore, when the context changes, the same characteristics may be associated with different outcomes for youth. Hoxhaj, M. (2017) argues in his paper that the liberalization of the education market in Albania resulted in the opening of many private universities, as well as the government's tendency to direct young people toward higher education in order to reduce youth unemployment in the short-run (while continuing the university was not counted as unemployed) carried on a pattern with the increase in the number of young people who began to attend higher education and technical training. But the limited employment market has to increase youth unemployment who have a university degree.

Hoxhaj, M. (2017) also states that the transition of the economy and its exit from the agricultural and public sector sectors, both of which have been very important in terms of employment, has had an impact on employment in Albania, as it has in many other transition countries. In recent years the labour market it is mostly focused on service sectors like hospitality and tourism. Due to the low number of proper vocational education schools in this field, the hotel and tourism sector has a significant shortage of skilled workforce and ready to work in this field.

Given that this sector has the potential to employ many young people has led to an increase in unemployment among them who do not meet this high demand of the labour market.

\subsubsection{Vocational education and training (VET) framework in Albania}

Albania has made steady progress in establishing democratic political institutions and a market economy since the fall of communism in the 1990s. Albania became a candidate country for European Union (EU) membership in 2014, and since then, it has pursued public sector reforms, including in education, as required for the start of EU accession negotiations. Education reforms are critical for fostering democratic citizenship and developing the skills and competencies required for Albania's longterm economic development. Education systems as explained in the figure below, perhaps more than any other systems, serve as sites of identity construction. Over the last few decades, schools' roles have shifted from reproducing loyal communist subjects to fostering the growth and development of students' critical-thinking and 
digital competencies in preparation for participation in Albania's society and economy and beyond ${ }^{1}$.

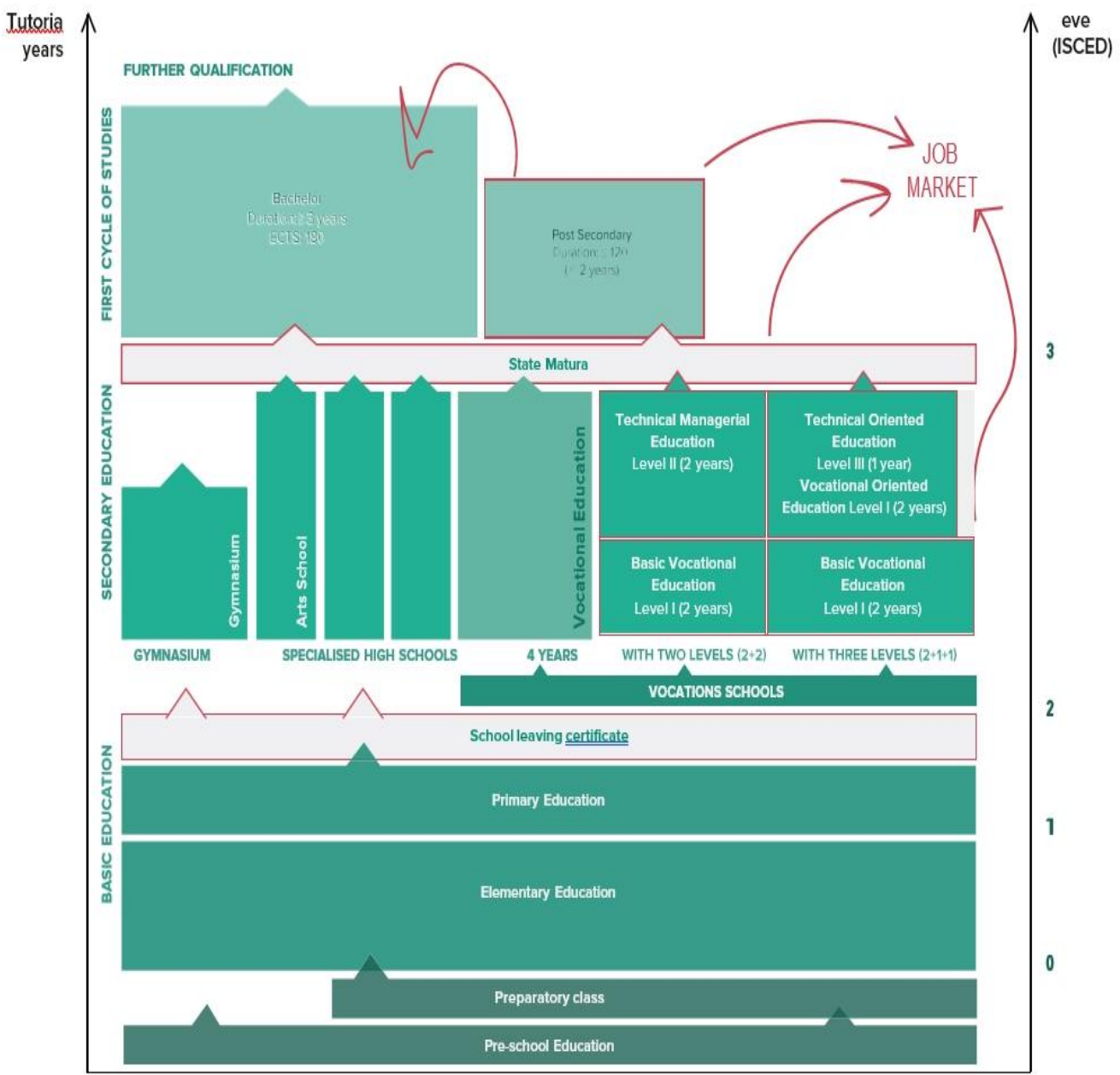

Figure. 1 Education system of Albania (www.vet.al; ECTS, European Credit Transfer System)

VET reform, as well as active employment and job creation policies, remain high on the Government's agenda, as demonstrated by budget increases in both areas. The vision of creating "higher skills and better jobs for women and men," as well as the four pillars of the National Employment and Skills Strategy, remain unchanged (2014-

\footnotetext{
1 UNESCO Section of Education Policy. (2017) Albania Education Policy Review: Issues and Recommendations. (p.10). [Online]Available:

https://www.researchgate.net/profile/TuuliKurki/publication/331011714_Albania_Education_Policy_ Review_Issues_and_Recommendations/links/5c6136baa6fdccb608b7b1d2/Albania-Education-PolicyReview-Issues-and-Recommendations.pdf?origin=publication_detail
} 
2015), namely: (i) fostering decent job opportunities through effective labour market policies; (ii) offering quality VET to young people and adults; (iii) promoting social inclusion and territorial cohesion; (iv) strengthening the governance of the labour market and qualification systems ${ }^{1}$.

Despite all reform efforts, there is still a significant skills shortage and skills gap in the Albanian labour market, owing primarily to insufficient collaboration between the worlds of education and work. According to UNDP Review of Albania's Vocational Education and Training System (2020, p. 9) the major accomplishments of the last six years of VET reform, since the adoption of National Employment and Skills Strategy (NESS), have been the establishment of a comprehensive legislative framework that defines the guiding principles and structure of the VET system, the roles and responsibilities of the key actors, and overall standards for VET provision, assessment, and certification, which include the following: the amended Labour Code (2015), the Craftsmanship Law (2016), a new VET Law (2017), the amended Albanian Qualifications Framework (AQF) Law (2018), the amended Pre-University Education Law (2018), and the Employment Promotion Law (2019). The challenge is to put this legal framework into action. VET has recently been centralized under the Ministry of Finance and Economy, which oversees a state-funded system comprised of two types of providers: vocational schools for young people and vocational training centers, mainly for adults.

The reforms aim to help Albania develop into a more competitive economy and socially inclusive society by improving and expanding technical skill opportunities for unemployed women and men in Albania, with a particular focus on youth, allowing them to find an attractive and decent job, but only minor progress has been made so far.

\subsubsection{Enhancing skills that facilitate the transition from school to work}

In Albania, the transition from school to work is complicated. The demand for young workers is influenced by the industry and service sectors and their stages of modernization, as well as the operation of labour market mechanisms. According to the figures, young people's access to the labour market in Albania is difficult and at very low levels. But as Hackaj, A. (2015, p.17) argue it is widely accepted that countries with a dynamic economy, a functioning market, and appropriate public policies have the smoothest labour market transitions for youth. They should, more precisely, have:

- a favourable demographic structure;

- a favourable macroeconomic situation;

- a high demand for youth labour;

\footnotetext{
1 Doe, J. (2021, March 31). National Reforms in Vocational Education and Training and Adult Learning. Eurydice - European Commission. https://eacea.ec.europa.eu/national-

policies/eurydice/content/national-reforms-vocational-education-and-training-and-adult-learning_en.
} 
- minimum wage rates;

- education and training systems that provide young people with required skills and prepare them for entry into the labour market;

- functioning welfare regimes that include active labour market programs.

As Hackaj, A. (2015, p.17) also states Albanian youth frequently face a protracted period of career insecurity as a result of a gloomy macroeconomic situation, dual labour markets, and education and training systems that lack elements of employer involvement and hands-on work experience. As a result, different transition experiences are caused by not only the level of educational attainment but also the quality of education and close links to the labour market. In general, countries with greater integration of school and work demonstrate a smoother and faster transition from school to work. They accomplish this through apprenticeship programs or by increasing the number of young people who effectively combine school and early labour market experiences. As a result, countries with a high level of specific vocational qualifications have lower youth unemployment.

\subsubsection{What skills are requested by the labour market?}

The Demand for Skills in Albania: An analysis of the Skills Towards Employment and Productivity Survey in 2018 provide two key sources of information on skill needs: (i) information on the types of skills used on the job by a "typical" high-skilled and lower-medium-skilled worker; and (ii) information on how employers rank the importance of different skills for jobs when recruiting.

This survey shows that workers use a combination of cognitive and socioemotional skills, particularly interpersonal skills, on the job. More than 75 percent of firms in Albania reported that workers in higher-skilled occupations use more new economy skills, which is consistent with the global skills shift toward higher-order cognitive and socioemotional skills, communication and problem-solving skills (tasks that require spending more than 30 minutes consecutively thinking and working on resolving an issue), client and team skills, as well as reading and numeracy, are all required. Workers in lower-medium-skilled occupations, as expected, use each skill less intensively than workers in higher-skilled occupations.

Jobs requiring a high level of skill are in high demand in dynamic firms. Dynamic firms, which are defined as innovative firms with international contacts, require more skills than other firms. In many of these firms, even foreign language skills are used by the typical higher-skilled worker (this is not surprising, given that they have international contacts). The use of cognitive skills is the most significant difference between dynamic and non-innovative firms; interpersonal skills are less important. Importantly, these firms have higher nonroutine skill requirements for lowermedium-skilled workers (team skills, making presentations, problem solving).

In the labour market as Albania when most businesses are family-based and employ at least one member of the family more studies are needed to determine which skills 
the market requires.

\section{Results and Discussion}

In conclusion, the Albanian progression towards an open market economy, being all by itself an ideal moment for the new business ideas, offered the labour force new opportunities for improvement. Then again, these new conditions put a disadvantageous skills trouble upon the workforce population, particularly upon the youth. The education system, including the vocational education and training system, was and is unfortunately unable to adapt in accordance with the rapidly changing market environment. Furthermore, the necessary supporting political policies to effectively upgrade this system were completely absent at the beginning of the $90 \mathrm{~s}$ and 00s.

In the last decade, the under-taken reforms of the vocational education system have some impact on the country's economic and social development. Taking everything into account, from the entirety of the previously mentioned studies and report, it is clear we need to consider and set up a help structure comprising of valuable administrations for the vocational education and training in improving workforce skills. A closer collaboration with the business local area is needed. Youth unemployment in Albania has been and is in high figures, the fundamental reasons are lacking proper skills for the labour market and the economic incapacity to generate jobs. Vocational education can increase young people's self-confidence and improves their economic and social lives by improving individual skills, particularly those related to work Sela, E. (2016). Various international studies have found that countries with a high level of specific professional skills have lower unemployment in this category Sela, E. (2016). Albania as a country with a young population should invest more in creating new opportunities for employment through a good vocational education and training system.

\section{References}

[1] Banerji, A. et al. (2010). "Stepping Up Skills for More Jobs and Higher Productivity." Washington, DC: World Bank.

[2] Doe, J. (2021, March 31). National Reforms in Vocational Education and Training and Adult Learning. Eurydice - European Commission. https://eacea.ec.europa.eu/national-policies/eurydice/content/nationalreforms-vocational-education-and-training-and-adult-learning_en.

[3] Hackaj, A. (2015). Youth employment trends in Albania: What is the market looking for? = Trendet e punësimit rinor në Shqipëri: Çfarë kërkon tregu? (pp.17) Friedrich-Ebert-Stiftung, Office Tirana.

[4] Harteis, Ch. (2017). Intuition as Crucial Component of Professional Competence: Its Relevance for Competence-based Vocational and Professional Education and Training. 10.1007/978-3-319-41713-4_45.

[5] Honorati, M. et al. (2018). Western Balkans - Demand for skills in Albania : an analysis of the skills towards employment and productivity survey (English). 
Washington, D.C. : World Bank Group. p. 23-24. http://documents.worldbank.org/curated/en/262231529562176390/West ern-Balkans-Demand-for-skills-in-Albania-an-analysis-of-the-skills-towardsemployment-and-productivity-survey

[6] Hoxhaj, M. (2017). Youth Unemployment in Albania, Causes and Consequences. EuroEconomica. Vol 36 , No 2.159-168.

[7] INSTAT 2017. "Labor Market 2016", INSTAT, Albania. http://www.instat.gov.al/media/4436/tregu-i-punes-2017.pdf

[8] Ministry of Education and Science., \&Ministry of Labour, Social Affairs and Equal Opportunities. (2012) Final Draft National Strategy for Vocational Education Training and Lifelong Learning 2013 - 2020. [Online] Available: https://www.etf.europa.eu/sites/default/files/m/2F2ABAD2B5A1126EC12 57B650030CA17_TRP\%202012\%20Albania_EN.pdf

[9] Sela, E. (2016). The challenges of vocational education in Albania, European Scientific Journal June 2016, 12 (16), 383-389. doi:10.19044/esj.2016.v12n16p383

[10] Serjanaj, L., \& Guga, K. (2017). The Determinants of Youth unemployment in Albania. [Online] Available: https://www.researchgate.net/publication/341979974_THE_DETERMINAN TS_OF_YOUTH_UNEMPLOYMENT_IN_ALBANIA

[11] UNDP Albania. 2020. Review of Albania's Vocational Education and Training System. [Online] Available: https://www1.undp.org/content/dam/albania/NewPublications/Review_A lbania's_VET_system_1.pdf.

[12] UNESCO Section of Education Policy. (2017). Albania Education Policy Review: Issues and Recommendations. p.10. [Online]Available: https://www.researchgate.net/profile/TuuliKurki/publication/331011714 _Albania_Education_Policy_Review_Issues_and_Recommendations/links/5c6 136baa6fdccb608b7b1d2/Albania-Education-Policy-Review-Issues-andRecommendations.pdf?origin=publication_detail

[13] "World Bank Group. 2018. Demand for Skills in Albania : An Analysis of the Skills Towards Employment and Productivity Survey. World Bank, Washington, DC. (C) World Bank. https://openknowledge.worldbank.org/handle/10986/30163 License: CC BY 3.0 IGO." 